52Al-Urban: Jurnal Ekonomi Syariah dan Filantropi Islam

Vol. 1, No. 1, Juni 2017

http://journal.uhamka.ac.id/index.php/al-urban

p-ISSN: 2580-3360 e-ISSN: 2581-2874

DOI: $10.22236 /$ alurban_vol1/is1pp52-67

Hal 52-67

\title{
PERANAN PEMBIYAAN MURABAHAH DALAM PENGEMBANGAN USAHA PADA PT BANK MUAMALAT
}

\author{
Rudi Abdullah
}

Universitas Muhammadiyah Buton

Email: rudi_tomia@yahoo.co.id

Diterima: 3 Mei 2017; Direvisi: 7 Mei 2017; Disetujui: 25 Mei 2017

\begin{abstract}
The purpose of this study to determine how the role of murabahah financing in developing the business at PT. Bank Muamalat Branch Baubau Assistant. The population in this study is 268 number of customers in Murabahah Financing At PT. Bank Muamalat Branch Baubau Assistant. The method used is descriptive method of collecting data obtained and then interpret and analyze it so as to provide information that can be used to solve problems encountered. The data used are primary data and secondary data. This research concludes that the role of murabahah financing product in BMI has applied financing principle in accordance with Fatma Dewan Syariah Nasional. 04 / DSN MUI / IV / 2000. About Murabahah in every financing transaction by paying attention to contract, sale price, financing requirement, term of financing, way of mortgage financing, and also pay attention to murabahah financing role at bank muamalat. The authors suggest that PDD BIM should improve professionally delivered, in terms of products, services, and implementation in accordance with sharia principles.
\end{abstract}

Keywords: Financing, Murabaha, Business Development.

\begin{abstract}
Abstrak
Tujuan dari penelitian ini untuk mengetahui bagaimana peranan pembiayaan murabahah dalam pengembangkan usaha pada PT. Bank Muamalat Cabang Pembantu Baubau. Populasi dalam penelitian ini adalah 268 jumlah nasabah dalam Pembiayaan Murabahah Pada PT. Bank Muamalat Cabang Pembantu Baubau. Metode yang digunakan adalah metode deskriptif yaitu mengumpulkan data yang diperoleh kemudian menginterpretasikan dan menganalisanya sehingga dapat memberikan informasi yang dapat digunakan untuk memecahkan masalah yang dihadapi. Data yang digunakan adalah data primer dan data sekunder. Penelitian ini menyimpulkan Bahwa peranan produk pembiayaan murabahah pada BMI telah menerapkan prinsip pembiayaan sesuai dengan Fatma Dewan Syariah Nasional No. 04/DSN MUI/IV/2000. Tentang Murabahah disetiap transaksi pembiayaan dengan memperhatikan akad, harga jual beli, persyaratan pembiayaan, jangka waktu pembiayaan, cara pembiayaan cicilan, serta memperhatikan peranan pembiayaan murabahah pada bank muamalat. Penulis menyarankan agar PDD BIM lebih meningkatkan profesionally delivered, baik dari segi produk, pelayanan, maupun pelaksanaannya sesuai prinsip syariah.
\end{abstract}

Kata Kunci: Pembiayaan, Murabahah, Pengembangan Usaha. 
Rudi Abdulah53

\section{PENDAHULUAN}

Perkembangan perekonomian yang semakin kompleks tentunya membutuhkan ketersediaan dan peran serta lembaga keuangan. Kebijakan moneter dan perbankan merupakan bagian dari kebijakan ekonomi yang diarahkan untuk mencapai sasaran pembangunan. Oleh sebab itu peranan perbankan dalam suatu negara sangat penting. Tidak ada satu negara pun yang hidup tanpa memanfaatkan lembaga keuangan. Lembaga keuangan menjadi sangat penting dalam memenuhi kebutuhan dana bagi pihak defisit dana dalam rangka untuk mengembangkan dan memperluas suatu usaha atau bisnis. Lembaga keuangan sebagai lembaga intermediasi berfungsi memperlancar mobilisasi dana dari pihak surplus dana ke pihak defisit dana.

Lembaga keuangan secara umum dibagi ke dalam dua jenis yaitu lembaga keuangan perbankan dan lembaga keuangan non bank. Lembaga perbankan merupakan lembaga keuangan yang berfungsi sebagai perantara antara pihak yang kelebihan dana dengan pihak yang kekurangan dana. Pada praktiknya, bank-bank ini menghimpun dana dari masyarakat berupa simpanan dan menyalurkan kepada masyarakat dalam bentuk kredit. Sementara itu lembaga keuangan non bank melakukan aktivitas salah satu dari fungsi bank, yaitu melakukan penghimpun dana saja dari masyarakat atau menyalurkan saja kepada masyarakat.

Ciri-ciri sebuah lembaga keuangan syariah dapat dilihat dari hal-hal sebagai berikut: (1) dalam menerima titipan dan investasi, lembaga keuangan syariah harus sesuai dengan fatwa dewan pengawas syariah; (2) hubungan antara investor (penyimpan dana), pengguna dana, dan lembaga keuangan syariah sebagai intermediary institution, berdasarkan kemitraan, bukan hubungan debitur-kreditur; (3) bisnis lembaga keuangan syariah bukan hanya berdasarkan profit oriented, tetapi juga falah orianted, yakni kemakmuran di dunia dan kebahagiaan di akhirat; (4) konsep yang digunakan dalam transaksi lembaga syariah berdasarkan prinsip kemitraan bagi hasil, jual beli atau sewa menyewa guna transaksi komersial, dan pinjam-meminjam (qardh/ kredit) guna transaksi sosial; (5) lembaga keuangan syariah hanya melakukan investasi yang halal dan tidak menimbulkan 
54AI-Urban: Jurnal Ekonomi Syariah dan Filantropi Islam

Vol. 1, No. 1, Juni 2017

http://journal.uhamka.ac.id/index.php/al-urban

p-ISSN: 2580-3360 e-ISSN: 2581-2874

DOI: $10.22236 /$ alurban_vol1/is1pp52-67

Hal 52-67

kemudharatan serta tidak merugikan syiar

Islam.

Lembaga keuangan bank di Indonesia telah terbagi menjadi dua jenis yaitu, bank yang bersifat konvensional dan bank yang bersifat syariah. Bank yang bersifat konvensional adalah bank yang dalam pelaksanaan operasionalnya menjalankan sistem bunga, sedangkan bank yang bersifat syariah adalah bank yang dalam pelaksanaan operasionalnya menggunakan prinsipprinsip syariah Islam. Prinsip syariah adalah prinsip hukum Islam dalam kegiatan perbankan berdasarkan fatwa yang dikeluarkan oleh lembaga yang memiliki kewenangan dalam penetapan fatwa di bidang syariah (UU, No. 21 Tahun 2008).

Bank yang berdasarkan prinsip syariah seperti halnya bank konvensional, juga berfungsi sebagai suatu lembaga intermediasi, yaitu mengerahkan dana dari masyarakat dan menyalurkan kembali dana tersebut kepada masyarakat yang membutuhkannya dalam bentuk fasilitas pembiayaan. Pembiayaan merupakan salah satu kegiatan utama dan menjadi sumber utama pendapatan bagi bank syariah.

Bentuk pembiayaan perbankan berdasarkan prinsip syariah antara lain 
Rudi Abdulah55

Aplikasi murabahah dalam perbankan syariah dapat dikategorikan pada pembiayaan konsumtif dan pembiayaan produktif. Pembiayaan konsumtif merupakan pembiayaan untuk keperluan konsumsi nasabah, antara lain; pembelian rumah, motor dan keperluan konsumsi keseharian lainnya. Sedangkan untuk pembiayaan produktif adalah pembiayaan yang terkait dengan modal kerja dan investasi.

Perkembangan lembaga keuangan syariah memiliki peranan yang signifikan pada pertumbuhan lembaga keuangan Indonesia. Peranan ini dibuktikan oleh partisipasi masyarakat menggunakan lembaga keuangan syariah untuk mengembangkan usahanya. Lembaga keuangan syariah sebagai bagian dari sistem ekonomi syariah, dalam menjalankan bisnis dan usahanya juga tidak terlepas dari jaringan Syariah. Oleh karena itu, Lembaga keuangan syariah tidak akan mungkin membiayai usaha-usaha yang di dalamnya terkandung hal-hal yang diharamkan, proyek yang menimbulkan kemudharatan bagi masyarakat luas. Bisnis syariah ditunjukan untuk memberikan sumbangan positif terhadap pencapaian tujuan sosial ekonomi masyarakat yang lebih baik. Bisnis secara syariah dijalankan untuk mencapai iklim bisnis yang baik dan lepas dari praktik kecurangan.

Permasalahan pembiayaan Bank Syariah yang menjadi masalah internal dari pihak Bank Syariah sebagai pemberi pembiayaan, secara umum diidentifikasikan sebagai berikut: petugas pembiayaan, baik marketing maupun analisis yang kurang memahaminya sektor usaha pada pembiayaan yang diberikan pembidangan pembiayaan belum dilakukan melalui spesialisasi segmen usaha, sehingga analisis belum memiliki pendalaman terhadap satu atau beberapa sektor usaha yang dianalisisnya, pemutusan pembiayaan yang kurang informasi mengenai usaha dan sektor ekonomi yang dibiayai.

Bank Muamalat Indonesia merupakan salah satu bank syariah di Indonesia yang menjalankan konsep Murabahah berdasarkan PSAK No. 102, yaitu akad jual beli barang dengan harga jual sebesar biaya perolehan ditambah keuntungan yang disepakati dan penjual harus mengungkapkan biaya perolehan barang tersebut kepada pembeli. Bank Muamalat Indonesia memberikan bantuan pembiayaan dalam bentuk pembayaran secara cicilan dan 
56Al-Urban: Jurnal Ekonomi Syariah dan Filantropi Islam

Vol. 1, No. 1, Juni 2017

http://journal.uhamka.ac.id/index.php/al-urban

p-ISSN: 2580-3360 e-ISSN: 2581-2874

DOI: $10.22236 /$ alurban_vol1/is1pp52-67

Hal 52-67

mempunyai beberapa sistem, prosedur dan

persyaratan yang harus dipenuhi oleh calon nasabah.

Menurut Muhammad (2005), sejumlah alasan untuk menjelaskan popularitas murabahah dalam operasi investasi perbankan Islam, yaitu: (1) Murabahah adalah suatu mekanisme jangka pendek dan dibandingkan dengan sistem Profit and Loss Sharing cukup memudahkan; (2) Mark up dalam murabahah dapat ditetapkan sedemikian rupa sehingga memastikan bahwa bank dapat memperoleh keuntungan bank-bank berbasis bunga yang menjadi saingan bank-bank Islam; (3) Murabahah menjauhkan ketidakpastian yang ada pada pendapatan dari bisnis-bisnis Profit and Loss Sharing.

Dalam hal ini, perbedaan pokoknya terletak pada jenis keuntungan yang diambil Bank dari transaksi-transaksi yang dilakukan. Bank Syariah melakukan kegiatan usahanya tidak berdasarkan bunga tetapi berdasarkan pada prinsip Syariah yaitu prinsip pembagian keuntungan dan kerugian. Ide dasar terciptanya Bank Syariah ini adalah upaya dalam menangkal sistem ribawi atau bunga yang ada pada Bank

Konvensional sebagaimana yang kita ketahui dari dulu. Dalam agama Islam terhadap proses riba ini sangatkah jelas yaitu Allah dengan jelas dan tegas sangat mengharamkan riba, sebagaimana ditegaskan Allah SWT dalam Al-Qur'an dan Hadis.

Berdasarkan dari alasan diatas maka operasional Bank Syariah harus mengikuti dan berpedoman kepada praktik-praktik usaha yang dilakukan menurut pada masa Rasullah SAW, bentuk-bentuk usaha baru yang tidak menyimpang dari ketentuanketentuan Al-Qur'an dan Al-hadis. Selain itu, berdasarkan hukum-hukum Syariah Islam Bank Syariah lebih mengutamakan unsur kepercayaan dalam pemberian pembiayaan ataupun proses kegiatan yang dilakukan mereka. Adapun beberapa macam produk jasa yang disediakan oleh Bank yang berbasis Syariah antara lain: Mudharabah Musyarakah, Mudharabah, Wadi’ah, Deposito Mudharabah dan produk lainnya.

\section{METODE PENELITIAN}

Dalam penyusunan penelitian ini, penulis melakukan penelitian dengan mengambil Obyek pada PT. Bank Muammalat Cabang 
Rudi Abdulah57

Pembantu Baubau. Populasi adalah seluruh kumpulan elemen yang menunjukkan ciriciri tertentu yang dapat digunakan untuk membuat kesimpulan (Sanusi, 2011). Populasi yang digunakan dalam penelitian ini adalah 268 jumlah nasabah dalam Pembiayaan Murabahah Pada PT. Bank Muamalat Cabang Pembantu Baubau.

Sampel adalah sebagian dari elemenelemen populasi yang akan terpilih. Dalam prakteknya seorang peneliti jarang sekali melakukan penelitian terhadap keseluruhan kumpulan elemen (populasi). Peneliti biasa melakukan seleksi terhadap bagian elemenelemen populasi dengan harapan hasil seleksi tersebut dapat merefleksikan seluruh karakteristik yang ada (Sanusi, 2011). Sampel yang di gunakan pada penelitian adalah jumlah pembiayaan murabahah disalurkan kepada masyarakat atau nasabah terhadap Peranan Pembiayaan Murabahah Dalam Pengembangan Usaha Pada PT. Bank Muamalat Cabang Pembantu Baubau.

\section{HASIL DAN PEMBAHASAN}

1. Landasan Hukum dan Pembiyaan Murabahah Perbankan Syariah

Agar sebuah produk dapat memberikan kemudahan dan ketenangan bagi si pengguna, maka harus ada payung hukum yang melandasinya. Bentuk legalitas hukum dari produk PHS Pemberian (murabahah) ini antara lain :

a. Undang-Undang Nomor 21 Tahun 2008 Tentang Perbankan Syariah Tanggal 16 Juli 2008.

b. PBI No 10/24/PBI/2008 tanggal 16 Oktober 2008 Tentang Perubahan Kedua Atas Peraturan Bank Indonesia No. 8/21/PBI/2006 Tentang Penilaian Kualitas Aktiva Bank Umum Yang Melaksanakan Kegiatan Usaha Berdasarkan Prinsip Syariah.

c. PBI No. 10/16/PBI/2008 Tanggal 25 September 2008 tentang Perubahan Atas PBI No.9/19/2007 Tentang Pelaksanaan Prinsip Syariah Dalam Kegiatan Menghipunan dana, Penyaluran Dana, Serta Pelayanan Jasa Bank Syariah.

d. PBI Nomor 10/17/PBI/2008 Tanggal 25 September 2008 Tentang Produk Bank Syariah dan Unit Usaha Syariah.

e. PBI Nomor. 9/19/2007 Tanggal 17 Desember 2007 Tentang Pelaksanaan Prinsip Syariah Dalam Kegiatan Penghimpunan dana Dan Penyaluran Dana Serta Pelayanan Jasa Bank Syariah. 
58Al-Urban: Jurnal Ekonomi Syariah dan Filantropi Islam

Vol. 1, No. 1, Juni 2017

http://journal.uhamka.ac.id/index.php/al-urban

p-ISSN: 2580-3360 e-ISSN: 2581-2874

DOI: $10.22236 /$ alurban_vol1/is1pp52-67

Hal 52-67

f. PBI Nomor 9/9/PBI/2007 Tanggal

18 Juni 2007 Tentang Perubahan Atas PBI

Nomor 8/21/PBI/2006 Tentang Penilaian

Kualitas Aktiva Bank Umum Yang

Melaksanakan Kegiatan Usaha Berdasarkan

Prinsip Syariah.

g. PBI Nomor. 8/21/PBI/2006 Tanggal

5 Oktober 2006 Tentang Penilaian Kualitas

Aktifa Bank Yang Melaksanakan Kegiatan

Usaha Berdasarkan Prinsip Syariah.

h. SE BI No. 10/14/DPbs Tanggal 17

Maret 2008 Tentang Pelaksanaan Prinsip

Syariah Dalam Kegiatan Penghimpunan

Dana Dan Penyaluran Dana Serta Pelayanan Jasa Bank Syariah.

i. SE BI No. 10/31/DPbs Tanggal 7

Oktober 2008 Tentang Produk Bank Syariah dan Unit Usaha Syariah, Dengan Lampiran Buku Kondifikasi Produk Perbankan Syariah.

j. SE BI No. 8/22/DPbs Tanggal 18 Oktober 2006 Tentang Penilaian Kualitas Aktiva Bank Umum Yang Melaksanakan Kegiatan Usaha Berdasarkan Prinsip Syariah.

o. Fatwa DSN Nomor. 19/DSNMUI/IV/2001 Tentang Al-Qardh.

p. Fatwa DSN Nomor. 31/DSNMUI/VI/2002 Tentang Pengalihan Hutang.

q. Fatwa Dewan Syariah Nasional No. 46/DSN-MUI/II/2005 Tentang Potongan Tagihan Murabahah.

r. Fatwa Dewan Syariah Nasional No. 47/DSN-MUI/II/2005 Tentang Penyelesaian Piutang Murabahah Bagi Nasabah Tidak Mampu Bayar.

s. Fatwa Dewan Syariah Nasional No. 73/DSN-MUI/XI/2008 Tanggal 14 
Rudi Abdulah59

November 2008 Tentang Musyarakah Mutanaqisah.

t. Anggaran Dasar PT. Bank Muamalat Indonesia Dan Perubahannya.

u. Buku kebijakan Umum Pembiyaan (KUP) PT. Bank Muamalat Indonesia.

v. Buku Prosedur Umum Pelaksanaan Pembiayaan (PUPP) PT. Bank Muamalat Indonesia.

w. Buku Kebijakan Umum Pembiayaan Bermasalah (KUPB) PT. Bank Muamalat Indonesia.

x. Buku Prosedur Umum Pelaksanaan Pembiayaan Bermasalah (PUPPB) PT. Bank Muamalat Indonesia.

y. Lembar Persetujuan DPS (Dewan Pengawas Syariah) PT. Bank Muamalat Indonesia, No.07/LP-DPS/BMI/VII/2010.

Landasan syariah untuk PHS Pembelian ini adalah Fatwa DSN No. 4 Tahun 2000 Tentang Murabahah seperti yang dikatakan oleh Kindy Miftah: “Landasan syariah untuk produk murahah Pembiayaan Hurnian Syariah Muamalat ini terdiri dari Fatwa Dewan Syariah Nasional No. 04/DSNMUI/IV/2000 Tentang Murabahah dan juga telah mendapat persetujuan dari DPS Bank Muamalat.”

2. Produk-produk Pembiayaan Murabahah Bank Muamalat Indonesia

Bank Muamalat Indonesia memiliki beberapa produk yang ditawarkan kepada para nasabahnya, seperti yang sudah tercantum dalam webside resmi PT. Bank Muamalat yaitu www.bankmuamalat.co.id. Produk-produk tersebut diantaranya adalah:

1. Pendanaan

1) Giro

a. Giro Muamalat Attijary iB. Produk giro berbasis akad wadiah yang memberikan kemudahan dan kenyamanan dalam bertransaksi. Merupakan sarana untuk memenuhi kebutuhan transaksi binis Nasabah perorangan maupun nonperorangan yang didukung oleh fasilitas Cash Managementi

b. Giro Muamalat Ultima iB. Produk giro berbasisi akad mudharabah yang memberikan kemudahan bertransaksi dan bagi hasil yang kompetitif. Sarana bagi nasabah perorangan dan non-perorangan untuk memenuhi kebutuhan transaksi bisnis 
60Al-Urban: Jurnal Ekonomi Syariah dan Filantropi Islam

Vol. 1, No. 1, Juni 2017

http://journal.uhamka.ac.id/index.php/al-urban

p-ISSN: 2580-3360 e-ISSN: 2581-2874

DOI: $10.22236 /$ alurban_vol1/is1pp52-67

Hal 52-67

sekaligus memberikan imbal hasil yang optimal.

ingin mendapatkan Bagi Hasil yang tinggi

bahkan setara dengan deposito.

2) Deposito

a. Deposito Mudharabah. Deposito syariah dalam mata uang Rupiah dan US Dollar yang fleksibel dan memberikan hasil investasi yang optimal bagi Anda.

b. Deposito fulinves. Deposito syariah dalam mata uang Rupiah dan US Dollar yang fleksibel dan memberikan hasil investasi yang optimal bagi serta perlindungan asuransi jiwa gratis bagi Anda.

2. Tabungan

a. Tabungan Muamalat, Tabungan syariah dalam mata uang rupiah yang akan meringankan transaksi keuangan Anda, memberikan akses yang mudah, serta manfaat yang luas. Tabungan Muamalat kini hadir dengan dua pilihan kartu ATM/Dbit yaitu Shar-E Regular dan shar-E Gold.

b. Tabungan iB Muamalat Prima. Sebagai bentuk dari komitmen PT. Bank Muamalat Indonesia, untuk memenuhi kebutuhan Nasabah dengan produk-produk yang inovatif, maka pada tanggal 13 Juli 2012 PT. Bank Muamalat Prima. Tabungan Perioritas yang di desain bagi Nasabah yang c. Tabungan iB Muamalat Rencana, Rencana dan impian di masa depan yang ingin kita wujudkan memerlukan keputusan perencanaan keuangan yang dilakukan saat ini, seperti perencanaan biaya pendidikan, dana persiapan pensiun/hari tua, biaya perjalanan wisata/ibadah, biaya pernikahan, biaya uang muka rumah/kendaraan, serta rencana atau impian lainnya. Tabungan iB Muamalat Rencana adalah solusi yang tepat untuk keputusan keuangan yang yang harus dilakukan saat ini untuk mewujudkan rencana dan impian di masa depan dengan cara yang sesuai prinsip syariah.

d. Tabungan Muamalat Umroh, Tabungan berencana dalam mata uang rupiah yang akan membantu anda mewujudkan impian untuk berangkat beribadah Umroh.

e. Tabungan Muamalat Dollar, Tabungan syariah dalam denominasi valuta asing US Dollar (USD) dan Singapore Dollar (SGD) yang ditujukan untuk melayani kebutuhan transaksi dan investasi yang lebih beragam, khususnya yang melibatkan mata uang USG dan SGD. 
Rudi Abdulah61

f. Tabunganku. Tabungan syariah dalam mata uang rupiah yang dikhususkan bagi anda masyarakat muslim Indonesia yang berencana menunaikan ibadah Haji.

\section{Pembiayaan}

a. Pembiayaan Konsumen ini dibagi menjadi lima produk yaitu : Pembiayaan Muamalat iB, Pembiayaan Automuamalat, Dana Talangan Porsi Haji, Pembiayaan Umroh Muamalat, Pembiayaan Anggota Koperasi.

b. Pembiayaan Modal Kerja adalah produk pembiayaan yang akan memebantu kebutuhan modal kerja usaha anda sehingga kelancaran operasional dan rencana pengembangan usaha anda akan terjamin. Pembiayaan modal kerja ini dibagi menjadi tiga yaitu : Pembiayaan Modal Kerja, Pembiayaan Modal Kerja LKM Syariah, pembiayaan Rekening Koran Syariah.

c. Pembiayaan Investasi adalah produk pembiayaan yang akan membantu kebutuhan investasi usaha anda sehingga mendukung rencana ekspansi yang telah anda susun. Pembiayaan investasi ini dibagi menjadi dua yaitu: Pembiayaan Investasi, Pembiayaan Syariah Bisnis.
3. Prosedur Pembiayaan Pada Bank Muamalat Indonesia

Dalam Bank Muamalat Indonesia ketika memberikan pembiayaan kepada nasabah, pihak BMI memiliki beberapa unsur yang perlu diperhatikan antara pihak perbankan sebagai kreditur dan calon nasabah sebagai debitur, hal-hal yang perlu diperhatikan adalah sebagai berikut:

1. Kepercayaan adalah suatu keyakinan dari pihak bank kepada calon nasabah bahwa pembiayaan yang berupa uang tersebut akan dikembalikan oleh nasabah tersebut. Sebelum pihak perbankan memberikan pembiayaan tersebut tentunya sudah dilakukan penelitian terhadap nasabah tersebut apakah nantinya layak diterima pengajuan pembiayaannya.

2. Kesepakatan Di dalam pembiayaan juga harus ada kesepakatan antara pemberi pembiayaan dan penerima pembiayaan. Dimana kesepakatan ini telah di atur dalam suatu perjanjian yang masing-masing pihak menandatangani hak dan kewajibannya.

3. Jangka Waktu Pada setiap pembiayaan dipastikan selalu ada jangka waktu pelunasan pembiayaan yang dari awal 
62Al-Urban: Jurnal Ekonomi Syariah dan Filantropi Islam

Vol. 1, No. 1, Juni 2017

http://journal.uhamka.ac.id/index.php/al-urban

p-ISSN: 2580-3360 e-ISSN: 2581-2874

DOI: $10.22236 /$ alurban_vol1/is1pp52-67

Hal 52-67

sudah ditentukan antara pihak bank dengan

adalah prosedur pembiayaan yang ada pada

nasabah.

4. Resiko Bisa dipastikan bahwa pada setiap pembiayaan selalu ada resiko yang bisa saja terjadi pada pihak perbankan. Resiko tersebut terjadi karena nasabah yang tidak mau membayar kewajibannya. Nasabah yang tidak mau membayar kewajibannya tergolong dalam dua tipe, yaitu nasabah yang mampu tapi tidak mau membayar kewajibannya dan nasabah yang tidak mampu melunasi kewajibannya disebabkan oleh nasabah yang mengalami kerugian atau bencana alam.

5. Balas Jasa. Dari pembiayaan yang telah memfasilitasi usaha dari nasabah, tentunya pihak perbankan mengharapkan suatu keuntungan dari dana yang telah dikeluarkan tersebut. Bagi bank konvensional keuntungan tersebut disebut dengan bunga bank, sedangkan bagi bank yang berdasarkan prinsip syariah bank mengharapkan keuntungan tersebut dari bagi hasil Dari pengertian di atas dapat di lihat apa saja unsur-unsur yang terkandung dalam pembiayaan. Begitu pula yang terjadi dalam PT Bank Muamalat Indonesia juga memakai unsur-unsur diatas. Berikut ini

1. Nasabah bertemu dengan marketing dari Bank Muamalat untuk mengajukan pembiayaan dan marketing tersebut langsung memasukkan Surat Permohonan 1 ke USP (Unit Support Pembiayaan). Surat Permohonan 1 berguna untuk proses tahap pertama dalam pembiayaan yang di ajukan.

2. USP menerima surat permohonan 1 dari marketing dan USP. Melakukan pengecekkan terhadap data nasabah yaitu menyangkut:

a. Bi Checking, yaitu untuk mengetahui calon nasabah yang mengajukan pembiayaan tersebut apakah masih mempunyai pembiayaan di Perbankan lainnya atau tidak.

b. Taksasi, yaitu bertujuan untuk mengetahui kelayakan usaha dari nasabah dan mengetahui keabsahan harga dari nilai aktiva yang akan di agunkan serta sebagai bahan bagi marketing atau komite pembiayaan dalam merekomendasikan pembiayaan.

c. Analisa Yuridis, bertujuan untuk melihat aspek-aspek kelegalitasan, keaslian 
Rudi Abdulah63

identitas dari nasabah yang mengajukan pembiayaan dan melihat jaminannya apa saja. Tetapi analisa yuridis hanya dilakukan untuk pembiayaan di atas Rp 250 juta. Dengan tahapan tersebut diharapkan menghindari bank dari resiko kerugian akibat nasabah cidera janji.

3. Setelah Bi Checking, Taksasi dan Analisa Yuridis selesai data-data tersebut diserahkan kepada Komite Pembiayaan untuk di nilai apakah pengajuan pembiayaan disetujui atau tidak.

\section{Setelah Komite Pembiayaan} menyetujui pengajuan pembiayaan tersebut, marketing segera menghubungi notaris untuk akad perjanjian atau pengikatan dalam pengajuan pembiayaan tersebut.

5. Setelah akad selesai dilaksanakan proses selanjutnya adalah Droping. Droping yaitu pencairan dana kepada nasabah yang mengajukan pembiayaan tersebut. Dan diharapkan nasabah tersebut dapat melunasi kewajibannya mengangsur setiap bulannya dengan jangka waktu yang sudah ditentukan.

\section{Peranan Pembiayaan Murabahah} Pada Bank Muamalat Indonesia.

Saat ini, pembiayaan syariah dapat dijadikan alternatif solusi bagi para pelaku usaha yang memiliki masalah dalam hal permodalan. Pembiayaan syariah pun memiliki peranan penting bagi para pelaku usaha yang ada di indonesia kedepannya terutama bagi para pelaku usaha tersebut. Peranan penting tersebut antara lain membuka peluang pembiayaan bagi kegiatan usaha berdasarkan prinsip kemitraan/partnership (Mahliza, 2011).

Konsep yang diterapkan adalah hubungan kerja sama infestasi yang harmonis (Murtual Investor relationship) yang berbeda dengan pola hubungan debitur dan kreditur yang antagonis (debtor to creditorrelationship) pada pembiayaan perbankan konvesional. Menurut Siregar (2002) yang menyatakan bahwa produk dan jasa yang ditawarkan pembiayaan syariah memiliki keunggulan berupa peniadaan pembebanan bunga yang berkesinambungan (perpetual interest effect), pembatasan kegiatan spekulasi pengutamaan kegiatankegiatan yang mewujudkan antara sektor keuangan dan sektor riil (linkages between financial sector and real sector), serta pembiayaan ditujukan kepada usaha. Usaha yang lebih diperhatikan nilai-nilai etika dan muralitas. 
64AI-Urban: Jurnal Ekonomi Syariah dan Filantropi Islam

Vol. 1, No. 1, Juni 2017

http://journal.uhamka.ac.id/index.php/al-urban

p-ISSN: 2580-3360 e-ISSN: 2581-2874

DOI: $10.22236 /$ alurban_vol1/is1pp52-67

Hal 52-67

Soetrisno (2004) merupakan bahwa

lambat. Total aset perbankan syariah hanya

pembiayaan syariah sangat cocok untuk sebesar $2 \%$ total aset perbankan nasional.

usaha yang mempunyai ketidakpastian

tinggi dan keterbatasan informasi pasar seperti usaha tersebut. Pada umumnya, usaha merasa terbebani dengan adanya sistem bunga yang diterapkan pada pembiayaan konvesional karena bunga tersebut indetik dengan upaya memperoleh keuntungan atas kerja sama antara pihak pemberi pembiayaan dengan pelaku usaha. Akan tetapi, adanya sistem bagi hasil dengan sistem jual beli yang diterapkan pada pembiayaan syariah dapat menghindari prinsip mendapat untung atas kerjasama orang lain tersebut.

Peranan perbankan syariah seharusnya dilihat sebagai peluang strategis untuk industri perbankan nasional dan juga perekonomian Indonesia di masa mendatang. Dengan demikian, ada beberapa catatan kritis yang penulis yang ingin sampaikan.

1. Undang-undang Perbankan Syariah telah disahkan oleh pemerintah bersama DPR RI pada pertengahan juni 2008 lalu. Tetapi, perkembangan industri perbankan syariah di negeri ini masih terbilang sangat

2. Industri perbankan syariah masih banyak memberikan pembiayaan yang berupa kredit konsumsi (Debt Financing). Data terbaru dari bank indonesia menunjukkan kredit konsumsi dengan kontrak murabahah atau transaksi jual beli merupakan komposisi pembiayaan terbesar industri perbankan syariah yang mencapai $60 \%$, sedangkan komposisi pembiayaan berupa equity financing atau kredit mudharabah (sistem bagi hasil) dan musyarakah (sistem partnership) masih di bawah 40\%. Ini adalah pertanda bahwa fungsi dan peran alami perbankan syariah belum lagi pro kepada perkembagan sektor riil. Oleh karena itu, perbankan syariah seharusnya lebih inovatif untuk mengembangkan produk-produk pembiayaan yang mengutamakan investasi kepada sektor riil seperti kredit mudharabah dan musyarakah ini.

3. Permasalahan pembiayaan murabahah yang tidak compliance, kredit konsumsi murabahah (debt financing) seolah-olah memberikan kesan bahwa perbankan syariah mencoba melepaskan diri 
Rudi Abdulah65

untuk mengambil resiko dalam berusaha.

Dalam Fiqh Muamalat, ada beberapa syarat yang harus dipenuhi dalam melaksanakan kontrak murabahah antara barang yang akan dijual harus exist dan dimiliki oleh penjual.

Dalam contoh kasus, untuk kredit perumahan dengan menggunakan kontrak murabahah, secara ideal, bank syariah seharusnya membeli dulu rumah yang akan dijual kepada nasabah daripada developer. Dengan kata lain bank harus memiliki rumah yang akan dijual kepada nasabah dan keuntungan yang diambil dari transaksi jual beli adalah halal sebagaimana Allah telah berfirman dalam QS Al Baqarah 275. Telah Allah halalkan jual beli dan mengharamkan riba.

Pada kenyataanya bank syariah tidak memiliki rumah yang akan dijualkan kepada nasabah. Bank hanya memberikan pinjaman (loan) dan tidak melakukan transaksi jual beli secara murni, disebabkan bank tidak mau mengambil resiko kredit yang tinggi dan cenderung untuk bermain aman. Dengan demikian kredit murabahah sama saja seperti pinjaman kredit bank konvensional. Bank hanya memberikan pinjaman dan nasabah harus mengembalikan pinjaman kepada bank ditambah dengan pembayaran bunga. Bunga bank sudah jelas haram karena kontrak yang dipakai ialah kontrak pinjaman dan mengambil keuntungan dari uang yang dipinjamkan adalah riba. Didalam ekonomi syariah uang bukan sebagai komoditi untuk meruap keuntungan melainkan ia adalah sebagai alat tukar didalam perdagangan.

Dengan demikian terlihatlah tidak adanya perbedaan mendasar antara pembiayaan murabahah dan pinjamam berbunga (interent loan). Pada kenyataanya, sistem perhitungan keuntungan murabahah dengan pinjaman berbunga bisa dikatakan sama. Pada bank konvensional perhitungan pinjaman berbunga ditunjukkan dengan persamaan $\mathrm{D}=\mathrm{L}(\mathrm{I}+\mathrm{rt})$. Dimana $\mathrm{D}=$ Debt (Hutang), L= Loan (pinjaman), $\mathrm{rt}=$ Rate of Interest (tingkat suku bunga). Sedangkan pembiayaan murabahah menggunakan model persamaan Pm = Pc $(I+r t)$, dimana $\mathrm{Pm}=$ Price of Murabahah (harga jual pembiayaan murabahah), $\mathrm{Pc}_{\mathrm{c}}=$ Price of cost (harga beli) dan $\mathrm{rt}=$ rate of profit (tingkat keuntungan antara perbankan syariah sama, tetapi secara filosofi dan kotrak seharusnya berbeda.

Jadi perbankan syariah harus lebih berani untuk mengambil resiko pembiayaan 
66Al-Urban: Jurnal Ekonomi Syariah dan Filantropi Islam

Vol. 1, No. 1, Juni 2017

http://journal.uhamka.ac.id/index.php/al-urban

p-ISSN: 2580-3360 e-ISSN: 2581-2874

DOI: $10.22236 /$ alurban_vol1/is1pp52-67

Hal 52-67

karena di dalam Fiqh Muamalat keuntungan

diberikan kepada bank, lalu ia menyiapkan

boleh diperoleh dengan adanya jual beli, risk

semua persyaratan yang diberikan oleh bank

sharing, dan juga investasi yang bersifat pada hari yang di tentukan oleh bank. Maka bagi hasil serta partnership. Apabila bank syariah memberikan kredit murabahah maka transaksi jual beli secara murni harus dilakukan. Walaupun total aset perbankan syariah masih dibawah 2\%. Dengan adanya peningkatan mutu dan pelayanan serta produk simpanan dan pembiayaan yang inovatif dan lebih syariah compliance, perbankan syariah akan berkembang dan tumbuh secara significant.

5. Usaha Yang Di Kembangkan Pada PT. Bank Muamalat

Dalam usaha yang dikembangkan pada Bank Muamalat selalu dikembangkan pada pedagang usaha kecil yang dimana usaha kecil itu selalu memegang dukungan permodalan pada bank muamalat contohnya seperti pengusaha kecil yaitu pedagang sendal sepatu, maka dari pada itu pedagang sendal sepatu ingin menambahkan modal sehinggah ia ditawarkan oleh bank untuk mengembankan modal usahanya agar usahanya maju dan berjalan dengan terus dengan baik. Pedagang sendal sepatu itu setuju dan ia mengikuti omongan yang dari itu pemberian modal usaha tersebut dengan individu atau badan ekonomi dengan kredit minimal 30 juta dengan target 24 bulan, dan kredit bank memberikan modal kepada pedagang untuk mengembangkan usaha menjadi besar. Jadi dalam hal ini angsuransi bulannan selalu wajib membayarnya tiap bulan dengan minimal 1,5 juta per bulan. Jadi pedagang sendal sepatu, usaha sudah berkembang dengan besar dan berjalan dengan baik.

\section{SIMPULAN}

Pembiayaan murabahah di Bank Muamalat sistem secara ansuran (murabahah muajjal), hal ini karena kebanyakan seseorang atau nasabah tidak akan datang ke bank kecuali mendapat kredit dan membayar secara ansur. Pada Bank Muamalat Indonesia banyak sekali nasabah yang mengajukan pembiayaan. Hal itu menunjukkan bahwa pada saat sekarang ini banyak nasabah yang membutuhkan pembiayaan untuk mengembangkan usahanya. Sehingga Bank Muamalat Indonesia melakukan prosedur atau tahapan dengan penuh kehati-hatian 
Rudi Abdulah67

\begin{tabular}{|c|c|}
\hline $\begin{array}{llll}\text { dalam } & \text { menyetujui } & \text { pembiayaan } & \text { yang }\end{array}$ & Anwar,Sanusi. \\
\hline dikeluarkan. & Bisnis. Jakarta: \\
\hline 3. Peranan perbankan syariah dalam & Empat. \\
\hline kehidupan perekonomian masyarakat & Sutrisno. $\quad$ (2004). \\
\hline sangatlah penting. Peranan tersebut & Research Jilid 3.Yogyakarta:Andi. \\
\hline diantaranya adalah untuk memenuhi & Mahliza, F. (2011). Analisis Faktor-Faktor \\
\hline kehidupan masyarakat akan tempat tinggal & yang Mempengaruhi \\
\hline yang layak. Dalam menjalankan aktivitasnya & Pembiayaan Murabahah \\
\hline perbankan syariah $\quad$ juga selalu & Usaha Mikro Agribisnis Sektor \\
\hline mengedepankan prinsip-prinsip syarıan. & Perdagangan(Studi Kasus: KBMT \\
\hline Wujud profesionalitas yang ditunjukan oleh & Bil Barkah. [skripsi]. Bogor: \\
\hline PT. Bank muamalat indonesia dalam & Fakultas Ekonomi danManajemen, \\
\hline pelayanan terbaıknya bagı nasabah salah & Institut Pertanian Bogor. \\
\hline satunya adalah & \\
\hline murabahah. & Muhammad, (2005). Pengantar Akuntansi \\
\hline & Syariah, Edisi 2. Jakarta: Salemba \\
\hline REFEREIVSI & Empat. \\
\hline & http://www.bankmuamalat.co.id/home/about \\
\hline & $/ \mathrm{p}$ \\
\hline
\end{tabular}

